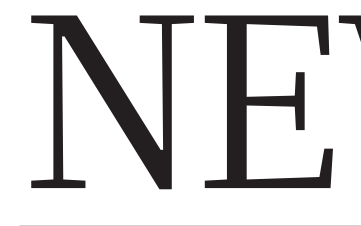

MAUNA KEA Mega-telescope reshapes sacred Hawaiian mountain p.15
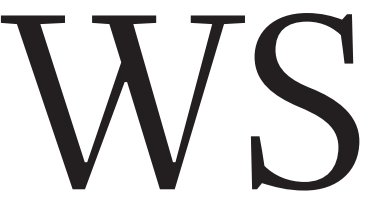

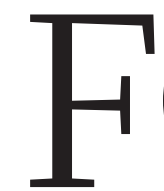

METROLOGY Hyper-accurate clocks prepare for mass comparison $\mathbf{p . 1 6}$
MÉDECINS SANS FRONTIÈRES Charity transformed by Ebola gets new clout $p .18$

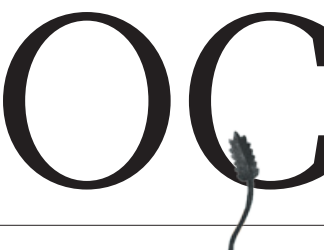

GENETICS Why CRISPR is the most disruptive technology since PCR p.20

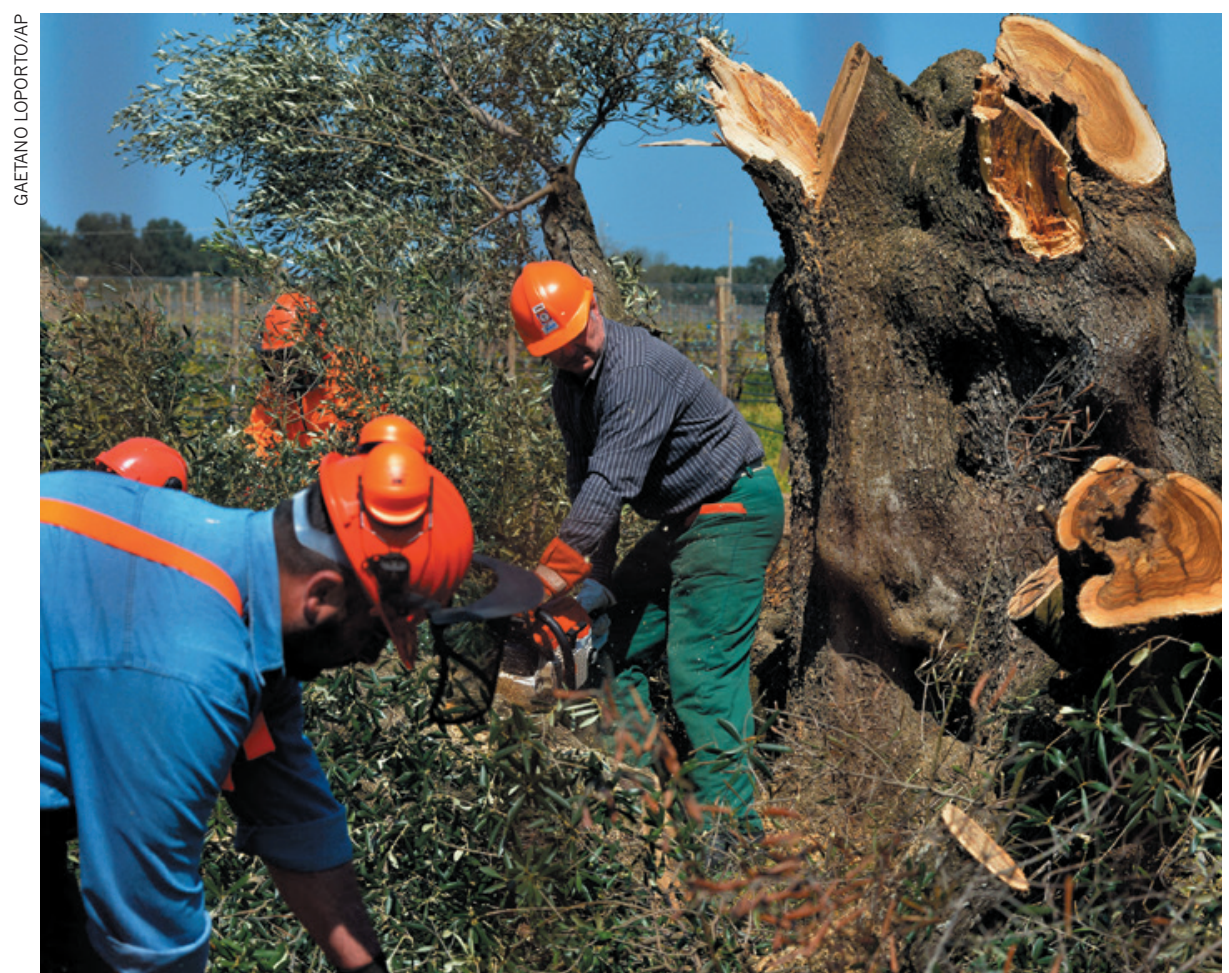

Workers in southern Italy cut down an olive tree infected with the deadly bacterium Xylella fastidiosa.

\title{
PLANT DISEASE
}

\section{Scientists blamed for olive-tree ruin}

\section{Italian police investigate researchers' role in a bacterial epidemic that is devastating Puglia's olive groves.}

\section{BY ALISON ABBOTT}

$\mathrm{T}$ They did not expect to be hailed as heroes, say the scientists tasked with researching a deadly pathogen that is ravaging olive groves in Puglia, southern Italy. But they certainly did not predict that they would end up feeling like villains.

In the past year, plant scientists at various institutes in Bari, the capital of the Puglia region, have seen their work and their motivations criticized by local campaigners. Most recently, they have been subject to a police investigation into whether they are responsible for the introduction of the bacterium, Xylella fastidiosa, into Puglia, or for allowing its subsequent spread.

Police have questioned several scientists involved in Xylella research and confiscated computers and documents from scientific institutes.

"We'd just like to be left to do our work without this suspicion and this stress," says Donato Boscia, head of the Bari unit of Italy's Institute for Sustainable Plant Protection (IPSP), whom police questioned in April.

"The scientists in Puglia working on the Xylella outbreak have been working nonstop for two years," adds Rodrigo Almeida, a Xylella specialist at the University of California, Berkeley. "Their reward has been to get attacked constantly — I just can't imagine how this would feel."

Xylella is endemic in parts of the Americas, including Costa Rica, Brazil and California, but was not previously found in Europe. That changed in October 2013, when scientists at the IPSP and the University of Bari identified ${ }^{1}$ the bacterium as the cause of an unusual disease outbreak in olive trees. The outbreak was immediately subjected to European Union (EU) regulations to limit its spread, and regional scientists began a systematic effort to understand the disease and contain it. Scientists went on to show that the bacterium was being carried by the spittlebug insect ${ }^{2}$.

From the start, farmers and environmentalists in Italy objected to containment measures, which involved uprooting trees and spraying the groves with pesticides. But trouble for the Puglian scientists began in April 2014, when individuals told police that they suspected the epidemic was caused by bacteria that scientists had brought from California for a European training course on Xylella at the Mediterranean Agronomic Institute of Bari (IAMB) in 2010.

Scientists say that this suggestion is ludicrous because the Puglia strain is different from the strains used at the workshop; the widely accepted theory is that the infection was imported with ornamental plants from Costa Rica, where the endemic Xylella strain matches the Puglia strain. However, the complaints spawned a much broader investigation by public prosecutors, including probes into what role scientists may have had in the epidemic. On 4 May, police confiscated computers and documents from the University of Bari and the IPSP, as well as documents from the Centre for Agricultural Research Basile Caramia in Locorotondo, Puglia. Two weeks later, police also seized documents from the Italian ministry of agriculture in Rome. The IAMB has voluntarily passed documents to police.

The prosecutors declined Nature's request for comment. But in March, one of them, Elsa Valeria Mignone, implied in an interview 
- with Famiglia Cristiana magazine that they are looking into theories that the bacterium may have been deliberately introduced into the area, or became entrenched because agricultural scientists failed to monitor the region properly, either deliberately or through neglect.

On 12 May, the Italian Association of Scientific Societies in Agriculture (AISSA), which represents 4,000 scientists in Italy, published a public letter defending the Puglian scientists and their work. "The claims do not have a scientific basis - that's what has shocked the scientific community," says Vincenzo Gerbi, AISSA president.

Puglian scientists have had to contend with public criticism, too. Several popular blogs devoted to the Xylella emergency have cast doubt on scientists' ways of working and their results - saying, for example, that a cure exists but is being suppressed. And Peacelink, an Italian non-governmental organization, wrote to the EU health commissioner in March saying that Xylella had not been proved to be the source of the outbreak, and that the deaths were instead the result of a fungus that could be

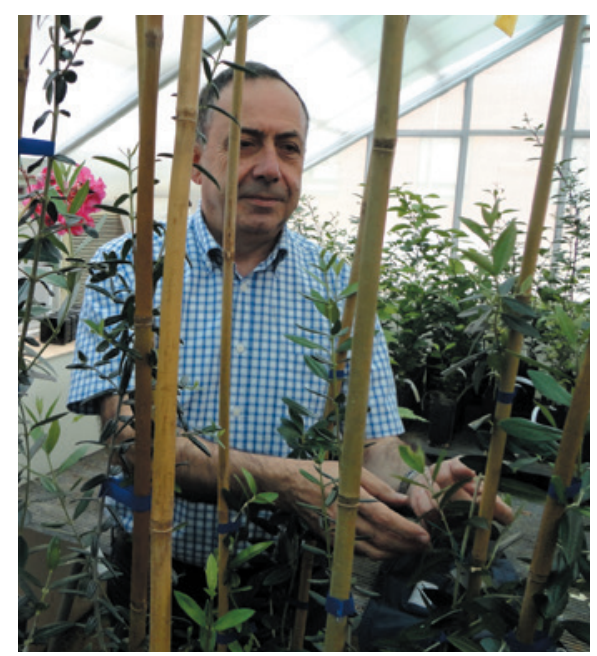

Donato Boscia researches Xylella fastidiosa at Italy's Institute for Sustainable Plant Protection.

eliminated without destroying trees. An expert panel of the European Food Safety Authority debunked these suggestions in a report published in April. "It's frustrating to hear all these complaints when you think you are doing a public service," says Anna Maria D’Onghia, head of the pest-management division at the IAMB, who has been questioned by police. "We are always being attacked for doing too little, or the wrong things."

Boscia says that the "attempts to delegitimize the results of scientific research" have been worse than the police investigations. But it is not all bad news for Puglian scientists. On 27 May, the regional government announced a $€ 2$-million (US\$2.2-million) fund for projects that might aid the diagnosis, epidemiology and monitoring of the bacterium. It said that a 'containment area' in the province of Lecce where the bacterium is now endemic, making complete eradication impossible - will be used as an open-air Xylella laboratory. National and European research agencies have also promised money, says Boscia. "The outdoor laboratory would be perfect for all of us - and also allow critics to put their own theories to the test." -

\section{Saponari, M., Boscia, D., Nigro, F. \& Martelli, G. P. J. Plant Pathol. http://dx.doi.org/10.4454/JPP. V95I3.035 (2013).}

2. Elbeaino, T. et al. Phytopathol. Mediterr. 53, 328-232 (2014).

\title{
Retracted gay-marriage study debated at misconduct meet-up
}

\author{
Over rum cocktails at the World Conference on Research Integrity, experts discussed what \\ can be learnt from the fallout of a flawed political-science paper.
}

\section{BY RICHARD VAN NOORDEN, RIO DE JANEIRO}

$\mathrm{T}$ he world's largest gathering of specialists in research misconduct kicked off on 31 May in Rio de Janeiro, Brazil, shortly after science's latest scandal broke. On the evening before the start of sessions on how to diagnose and remedy ethical faults in research, delegates to the 4th World Conference on Research Integrity sipped caipirinhas, Brazil's national cocktail - and swapped views on what could be gleaned from a flawed politicalscience study.

The paper in question, which claimed to show that short conversations with a canvasser who is gay could encourage voters to support same-sex marriage, made headlines across the world when it was published in Science last December (M. J. LaCour and D. P. Green Science 346, 1366-1369; 2014) - and again when it was retracted last week (Science http://doi. org/4zt; 2015). "The case is very much on our minds," said Melissa Anderson, a co-organizer of the meeting who studies scientific integrity at the University of Minnesota in Minneapolis.

Although the case throws up new instances of misconduct, and of inadequate supervision by senior academics, delegates to the Rio conference felt that, in general, the case illuminated little about the academic system that a steady drip-drip of research misconduct has not already highlighted. The main challenge, said Brian Martinson, a social scientist at the HealthPartners Institute for Education and Research in Minneapolis, is how to create a supportive environment that incentivizes reliable, reproducible research. "A lot of people think the bad stuff in science comes from academics being greedy or narcissistic - but that ignores how the structural arrangements in science, like the decline of funding and stable academic positions in the United States, leads people into bad behaviour," he said. In the latest twist in the debacle, co-author Michael LaCour, a graduate student in political science at the University of California, Los Angeles (UCLA), has admitted to misrepresenting his funding sources and the incentives he used to attract people to take part in the study. In a 29 May online reply to researchers who had spotted irregularities in his survey data (see go.nature.com/acpxnh), LaCour said that he had deleted his raw data for reasons of confi"Antiality and admit"Academia ted that he did not get should be concerned that its system of checks and balances has problems." ethical approval from an institutional review board before he did the work, or before he submitted it to Science. The document did not include convincing evidence that he had conducted the surveys.

LaCour told The New York Times that he stands by his finding - but his co-author Donald Green, a political scientist at the University of Columbia in New York City, does not: Green requested the paper's retraction after three outside scientists told him about irregularities in its survey data, and he apologized for 